\title{
Research on the Two Level Dissemination Characteristics of Posters_-Take the US Propaganda Picture during the Korean War as an Example Rao Wei
}

\author{
Zhongnan University of Economics and Law, No. 182 Nanhu Avenue, East Lake New Technology \\ Development Zone, Wuhan, Hubei, China \\ 10148031@qq.com
}

Keywords: Korean War, propaganda picture, US Army, two level communication

\begin{abstract}
The Korean War was the first large-scale war between countries after World War II. The United Nations Army led by the United States launched a war with the Chinese People's Volunteer Army and the Korean army. During the war, the propaganda pictures were widely used in all corners of the war because of their rich themes, vivid pictures, timeliness of communication and intuition of images. As a special media in war, propaganda pictures not only reflect the artistic value, but also highlight its important role as a weapon of war. Looking back on the Korean War in 1950, the use of propaganda posters in spreading psychological warfare in the United States is still one of the focuses of current scholars. This paper takes the propaganda pictures of U. S. military during the Korean War as the research object, through this special form of media, from the perspective of "secondary communication" theory, analyzes the use of U. S. military propaganda pictures during the Korean War.
\end{abstract}

In 1950, the well-known Korean War broke out, the United Nations Army led by the United States and the Chinese People's Volunteer Army and the Korean army launched a war, the front battlefield, the enemy and our two sides fight to the death. However, on the other side of the battlefield, a war of soft weapons without smoke is rapidly forming. During the war, the propaganda pictures were widely used in all corners of the war because of their rich themes, vivid pictures, timeliness of communication and intuition of images. As a special media in war, propaganda pictures not only reflect the artistic value, but also highlight its important role as a weapon of war. The United Nations Army, led by the United States, distributed a large number of posters, wartime posters and leaflets. Using powerful media organizations, it soon found a more shortcut in communication "secondary communication" theory. The United States Army led by the United States will be called "the US Army" for the time being. It is undeniable that the U. S. Army in World War I and World War II have fought a beautiful psychological war of communication, the reform of propaganda posters has also been one of the rapid development forward, becoming the object of each country and regime to emulate. However, in the Korean War period, the US military spread psychological warfare in the use of propaganda pictures, although the early play a certain effect, but also has its own shortcomings.

\section{The importance of "two pole propagation" theory in propaganda paintings}

Posters are also called posters. A painting with the aim of propaganda and encouragement combined with short call for words, usually referring to Political Poster. Generalized propaganda paintings, including posters and commercial advertisements for cultural activities, have the characteristics of simple and prominent shapes and bright colors. Most of them are copied and posted on the streets or public places. They evolved from the early picture leaflets. It is precisely because of the characteristics of the poster that it acts as a soft weapon in the war. In the war, the style of the poster is different, the form is diversified, and the mode of transmission is also more. Because when used in wartime, a lot of content revolves around the contents of the war, especially from the 
different angles of the enemy and ourselves. Its content is rich and varied, the theme is clear, profound, concise and clear, easy to understand, so that the audience can be very infectious and persuasive in a relatively short period of time, to achieve the purpose and effect of its dissemination. During the Korean War, the propaganda pictures of the U. S. Army used the theory of "secondary communication" as their mode of transmission to influence the psychology of the Chinese volunteers, the Korean army and the people, so that the contents of the propaganda pictures could be spread in a wider range.

The theory of "secondary communication" was put forward by American communication scientist Lazarsfield in his book "People's Choice". It means that the mass media first transmits the information to the audience, and the person affected by the information is the "leader of public opinion", and then the "leader of public opinion" transmits the information obtained by himself and influences others. The theory of "two levels of communication" has been throughout the dissemination process of American propaganda pictures. Especially in this process of communication, "public opinion leaders" play a greater role. At this time, "public opinion leaders" through the informal way to influence the attitude of the poster audience, and provide advice or advice; or to a certain extent to change the behavior of the audience, in the process of subtle influence of others indirectly or directly. Its importance is mainly reflected in three aspects: first, "secondary communication" is a face-to-face special mode of communication, the content of the U. S. military poster to the audience left a direct impression, relatively easy to eliminate the ideological barriers of the audience, effectively eliminating the other side's psychological defense. Secondly, because of the influence of the education level of the Korean people, the content of the poster is not transmitted directly to the ordinary audience, but to different target audience groups according to different information. Therefore, these target audience groups will act as "public opinion leaders" and pass these messages to more ordinary audiences through other means, so that the content of the poster and the ordinary audiences receive information from all aspects to achieve a high degree of consistency. Thirdly, although there are many "public opinion leaders" in the process of dissemination, the characteristics of rapid production and dissemination of posters, as well as the rapid increase of audience groups, make the effective scope of dissemination wider.

\section{The application of the theory of "two pole propagation" in the propaganda paintings of the US Army}

In the Korean battlefield, the shadow of secondary communication mostly exists in some negative material, or the United States, which has always advocated black propaganda strategy, pays more attention to the widespread impact of these false propaganda pictures. It seems that the propaganda of its own strong justice is far less direct than the vilification of the other side, and the public opinion leaders in the audience are more direct. It has played a strong guiding role in a period of time. It can be said that the achievements of the U. S. military poster, in a period of time, has become more effective in the U. S. military than thermal weapons in special weapons.

\subsection{Posters involving military alienation}

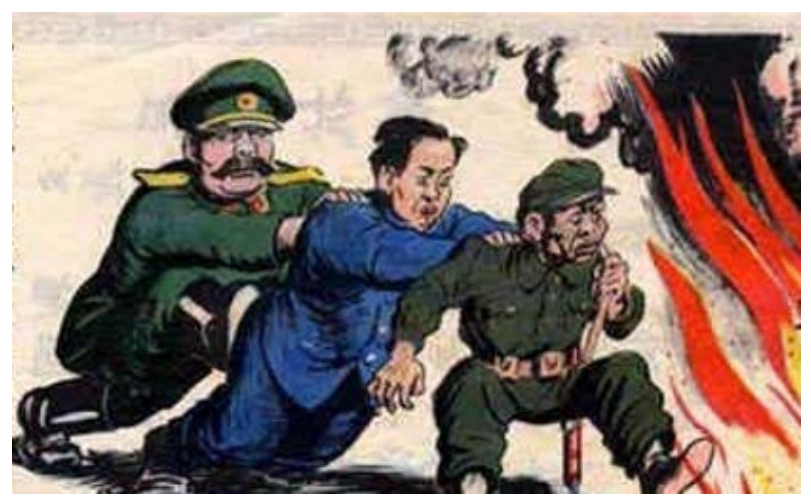

Figure1 
As shown in Figure 1, the Chinese soldiers are forced to fight in North Korea. The Soviet Union is behind them to instigate the implementation of the Communist Party of China. Finally, the two forces push the Chinese soldiers to the front and send them to the cruel battlefield. Try to dispel the authority of the leader in the eyes of the Chinese people's volunteer officers. These practices are reflected in the strategy adopted by the US Army.

Such propaganda is not uncommon on the Korean battlefield. Its purpose is to mislead Chinese soldiers on the battlefield and weaken their morale so as to win without fighting and break up the military spirit. Therefore, in this propaganda picture is mainly through the spread in the army to achieve a wide range of psychological break-up of soldiers. In the army, the propagation process of this poster is a typical two level communication. It can not be denied that as soldiers in the "high moral" role had been misled in such posters, the picture conveyed "deception", "slavery", "coercion" and other descriptions of the Communist Party of China, the Soviet Union, the behavior of information, once in a short period of time filled the entire battlefield, confused some officers and soldiers heart. These confused officers and soldiers naturally became the "leader of public opinion". To a large extent, these "public opinion leaders" come into contact with posters, keen to understand the battlefield dynamics and concern about politics. Therefore, these people also have a wide range of information sources, access to information earlier, the number of information and so on. They are morale-minded in the battlefield, dare to fight against injustice, charge into battle, won the trust of ordinary soldiers, soldiers willing to believe them. It can be said that these "public opinion leaders" have the characteristics of the unity of "followers", the directness of the field of influence and the activity of communication consciousness. Under such conditions, even if "public opinion leaders" spread unrealistic information, to a certain extent also caused a lot of negative effects.

In the dissemination of psychological warfare, the effectiveness of communication is the first. Whether the propaganda content is true or not is closely related to the information transmission and reception environment of the warring parties at that time. The design of the propaganda pictures of American psychological warfare has a strong pertinence, and refines the audience groups, the effect on the dissemination of the audience is more obvious. In Figure 1, we can see from the content that the division of the enemy's internal levels, the purpose is to make the enemy alliance between the mutual suspicion, disruption of the military, thus slowing down the enemy's operational efficiency, is beneficial to our strategy and tactics. This strategy adopted by the US military is based on the objective situation of multi-party involvement in the Korean War.

\subsection{Threatening type publicity poster}

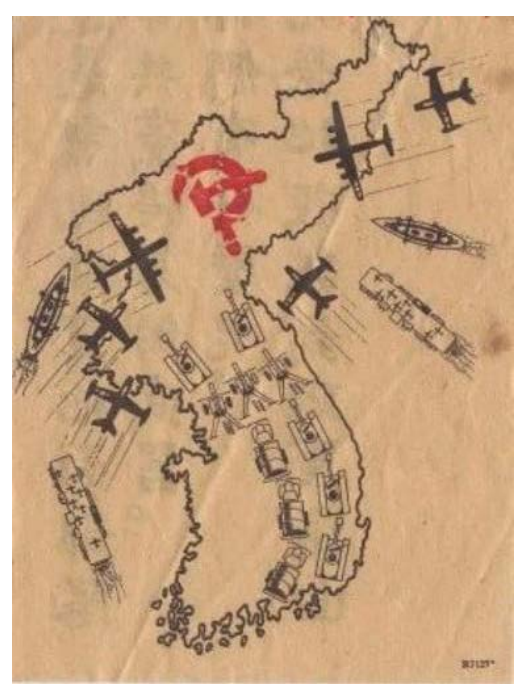

Figure2

As shown in Figure 2, the U.S. military poster advertises the United Nations Army's killing weapons, which directly demonstrate the sophistication and diversity of weapons. In the aspect of weapon deterrence propaganda, the U.S. military has a special intention to display all kinds of killing weapons, such as aircraft, artillery, tanks and so on, in order to foil the Chinese army's encounter 
with the U.S. weapons, like pebble to pebble. Therefore, the gap in weapon strength makes the US military choose to publicize the superiority of its own war weapons to deter the Chinese army in the propaganda of psychological warfare.

There are two ways to analyze the purposes of the US Army. Firstly, the fighting mentality that threatens Chinese army officers and soldiers; secondly, it is widely spread among Chinese army to exaggerate an overwhelming superiority in an attempt to break up the firm fighting determination of Chinese army. In the battlefield of threatening propaganda, the panic has been lost. In particular, some officers and soldiers who have a good understanding of these advanced weapons understand the serious consequences of the gap between the strength of our weapons and the enemy on the battlefield. Therefore, some of the officers and soldiers affected by such poster play the role of "public opinion leaders". These "public opinion leaders" played a great role in the further propaganda of the U. S. military propaganda posters. They propagated and even exaggerated the political intentions of the U. S. military one by one. At one time, they had a great impact on the psychology of the Chinese army, aimed at shaking the morale of the army on the battlefield. The US Army has targeted design in the publicity poster, making full use of the role of "public opinion leader". Although the use of intimidating propaganda pictures by the U.S. military has caused panic to the Korean people and some Chinese volunteers, the U.S. military has ignored the firm will of the Chinese volunteers to win, and has forgotten how the Chinese volunteers grew up in the smoke of gunpowder. However, in the Chinese Volunteer Army at that time, this method of intimidation failed to achieve its desired effect.

\subsection{Kinship series}

According to historical records, a large number of propaganda paintings used the words and styles of Korean and Chinese propaganda paintings in order to achieve more direct propaganda effect.

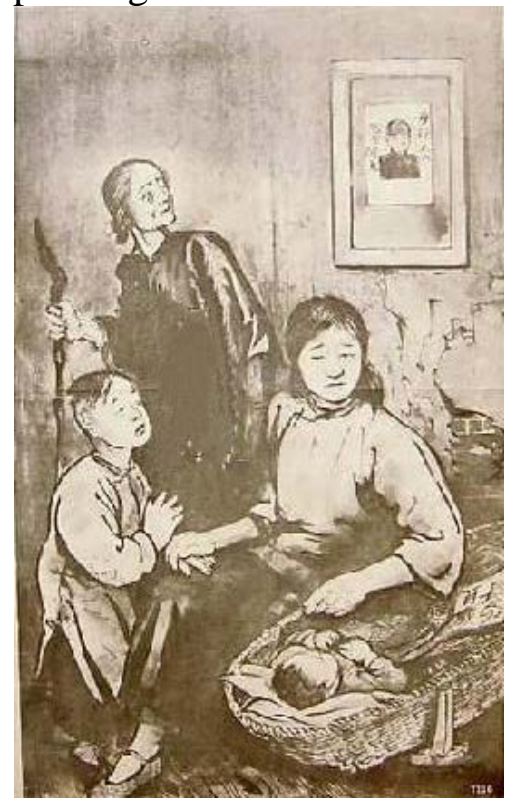

Figure3

As shown in Figure 3, the picture is rich in content, visual and intuitive, and less distributed. This kind of poster is widely spread among the Chinese volunteers and the masses, intending to convey a negative message of "compulsory" conscription to the ordinary people, while constantly arousing the feelings of homesickness of the volunteers. Through the content of the poster, the audience will miss their loved ones and deeply grieve for the loss of their loved ones. On the one hand, the U.S. military tried to show it to the volunteers, confusing their firm hearts; on the other hand, it tried to use the opinion leaders of the common people, such as some elders in the family, to play a strong central role in the spread of the family, causing panic and resentment. The US military camp in the Korean battlefield attaches great importance to the implementation of psychological warfare, such means of communication, so that the US military achieved the desired results. But the US military's seemingly 
habitual excessive distortion of facts on the Korean battlefield has backfired in the end. We should know that the confirmation of the effect of bipolar communication theory is based on interpersonal communication, and the most important point of interpersonal communication is to grasp the actual situation and respect people's psychology. Interpersonal communication, which is different from fact, is often futile.

Obviously, the US military's use of "secondary communication" means immature, this type of propaganda not only did not succeed in separating the Soviet Union and China and even Korea friendly relations, but also aroused the morale of the Chinese volunteers. The spread of psychological warfare in the "secondary transmission" mode, due to the U. S. military's misjudgment of the war situation, although achieved short-term self-interest, but ultimately consolidated the alliance between China and the Soviet Union. Therefore, in the process of the theory and practice of "secondary communication", it can be used as a reference for many members to participate in psychological warfare in the same battlefield.

\section{Conclusion}

To sum up, the U. S. military posters played an important military role in the Korean War, the application of posters in the dissemination of psychological warfare has also been developed, and become the object of various countries and regimes to emulate. American military posters make full use of the principle of limited and conditional interpersonal relationship in bipolar communication, so that the posters can realize the ideal role of mass communication in the audience.

Nowadays, with the rapid development of the Internet era, people's high demand for information, posters as a special media to disseminate psychological warfare is particularly important. In recent years, scholars at home and abroad are also constantly exploring the application of posters in the dissemination of psychological warfare, especially the application of secondary communication theory. Therefore, the author hopes that in such studies, it is imperative to regard interpersonal relations and opinion leaders as the key points, learn from the experience and lessons of the war application of the US military posters on the Korean battlefield, re-examine the historical development process, redefine the social and historical responsibilities of the researchers of communication psychological warfare, and promote world peace. Exhibition service.

\section{Acknowledgement}

This research is funded by Zhongnan University of Economics and Law's "Central University basic research business fee project [31541110315]".

\section{References}

[1] Lawrence Leshan, Psychology of War, Translated by Link, Renmin University of China Press, October 1, 2011.

[2] Fang Jianyi, Zhang Qin, Media Psychology (Modern Communication), Zhejiang University Press, September 1, 2004.

[3] Lazarsfield, (US) Berelson, (US) Gaudet, The Choice of the People, Translated by Tang Xi, Renmin University of China Press, June-01, 2012.

[4] Lexicon (M). Shanghai Shanghai Dictionary Publishing House, 1986 edition.. 